\title{
Música em tempos sombrios: apontamentos sobre a estética musical no III Reich
}

\author{
Music in Dark Times: Notes on the Musical Aesthetics in the III Reich
}

\author{
Lia Tomás \\ Universidade Estadual Paulista "Júlio de Mesquita Filho", São Paulo, São Paulo, Brasil. \\ liatomas@uol.com.br
}

Resumo: No Terceiro Reich, a música ocupou um papel de destaque entre as artes, pois foi maciçamente utilizada como instrumento ideológico. As diretivas estéticas propostas por Goebbels em 1938 tomavam por base um ideário já apontado em Quantz e Wagner, mas cuja reatualização distanciava-se do contexto original para cumprir outros fins. A partir de análises dos textos dos autores citados, o artigo visa demonstrar a apropriação das ideias centrais e suas transformações, bem como a criação de uma outra categoria de música, a saber, os monumentos musicais.

Palavras-chave: Música no Terceiro Reich; Wagner e Quantz; Goebbels e monumentos musicais.

Abstract: In the Third Reich, music occupied a prominent role among the arts, being heavily used as an ideological tool. The aesthetic guidelines proposed by Goebbels in 1938 were based on an ideology already pointed out by Quantz and Wagner, but whose context, in order to fulfill other purposes, distanced from the original context. Departing from an analysis of these authors' texts, this article seeks to demonstrate the appropriation of the central ideas and their transformations, as well the creation of a different category of music, namely, the musical monuments.

Keywords: Music in the Third Reich; Wagner and Quantz; Goebbels and musical monuments.

Data de recebimento: 05/02/2016

Data de aprovação final: 15/04/2016 


\begin{abstract}
A afirmação de que Hitler destruiu a cultura alemã não passa de um truque publicitário daqueles que pretendem reconstruíla a partir dos telefones de seus escritórios. O que Hitler erradicou em matéria de arte e pensamento há muito já levava uma existência dissociada e apócrifa, cujos últimos refúgios foram varridos pelo fascismo. Quem não se dispunha a tomar parte no jogo já se via forçado, anos antes do advento do Terceiro Reich, a refugiar-se na emigração interna: pelo menos desde a estabilização da moeda alemã, que coincide no tempo com o fim do expressionismo, a cultura alemã justamente se estabilizou no espírito do lema nazista "A força pela alegria", das autoestradas do Reich ou do elegante e desenvolto classicismo das exposições dos nazistas.
\end{abstract}

Adorno, Retorno à cultura (35), Mínima Moralia.

Diferentemente do que ocorrera em outros regimes totalitários da primeira metade do século XX, as artes desempenharam um papel crucial na propagação e manutenção ideológica do Terceiro Reich. No que se refere à música, seu uso como instrumento legitimador de um ideário político foi massivo e disseminado, recebendo o apoio integral do Estado na manutenção de orquestras, concertos, casas de óperas, grupos de câmara, escolas de música, universidades, bem como em eventos e paradas militares.

Cabe lembrar, entretanto, que esse apoio integral concedido à música após a chegada do Nacional-Socialismo ao poder nos anos 30, foi pautado por uma agenda política que prescrevia explicita ou implicitamente, as diretivas de tal fomento: difusão da música de compositores alemães (sobretudo Beethoven e Wagner), censura de compositores alemães ou não, cuja música fosse julgada como inadequada ou transgressora, difusão de canções folclóricas e sua respectiva incorporação no hinário patriótico, apoio as agremiações ou associações musicais profissionais ou amadoras, veto aos gêneros musicais populares internacionais, entre outros.

A partir do decreto das leis raciais de 1933, uma das primeiras medidas do regime nazista foi constituir em 22 de setembro do mesmo ano, a Câmara de Cultura do Reich (Reichskulturkammer), instituição afiliada ao Ministério da Propaganda e presidida por Joseph Goebbels, e exigir o registro de todos os músicos alemães. Fora a interrupção da carreira profissional de inúmeros compositores e intérpretes, pelo simples fato de sua raça e/ou critérios estilísticos das composições serem 
TOMÁS, Lia. Música em tempos sombrios: apontamentos sobre a estética musical no III Reich. Per Musi. Ed. por Fausto Borém e Lia Tomás. Belo Horizonte: UFMG, n.35, p.79-99.

classificadas como degenerados, outras medidas balizadas por uma ideologia conservadora e assertiva estavam por vir. Como exemplo, citamos a indicação de Alfred Rosenberg em 1934 como Plenipotenciário do Führer para a Total Capacitação Intelectual, Ideológica e Educacional do Partido Nacional-Socialista Alemão dos Trabalhadores (DBFU-NSDAP), cuja atribuição neste posto era fiscalizar ideologicamente todos os campos das artes, cultura e ciências e posteriormente a fundação do Einsatzstab Reichsleitter Rosenberg (ERR) em 1940, também liderada por ele, uma unidade operacional cuja missão era confiscar, nos países ocupados, todo o material artístico considerado importante para a Alemanha (TOMÁS, 2013).

Como nos informa Albert Dümling (2004: 117), as "Jornadas Musicais do Reich" (Reichmusiktage), ocorridas entre 22 a 29 de maio de 1938 em Düsseldorf, foram as primeiras manifestações de envergadura organizadas pelo regime com o intuito de apresentar um panorama representativo dos diferentes aspectos da criação e do patrimônio musical nacional. A programação era extensa e compreendia concertos sinfônicos, música de câmara, apresentações de óperas e operetas, três congressos (um de musicologia cujo tema era "Música e Raça", outro do Bureau de Concertos e ainda outro consagrado ao "Canto e Fala"), um encontro da Juventude Hitlerista, concertos em fábricas destinados aos operários e também ao ar livre com a presença de bandas e fanfarra, e a famosa exposição "Música Degenerada", capitaneada por Hans Severus Ziegler, a qual propunha uma retrospectiva crítica sobre a República de Weimar. No decorrer dessa intensa programação, Joseph Goebbels realiza um pronunciamento em 29 de maio, no qual proclama diretivas político-culturais no discurso "Os Dez Princípios para a Criação da Música Alemã", cujo teor veremos a seguir:

Este festival de música é, pela primeira vez, uma revisão da cultura musical em nosso tempo. Ele relata o que temos feito e estabelece os objetivos tanto para o futuro imediato quanto para o futuro previsível. Que a fama da Alemanha como a nação da música seja, uma vez mais, revelada e fundamentada aqui nesta ocasião. E acima de tudo, que os princípios, que desde tempos imemoriais foram a fonte e a força motriz de nossa música alemã, voltem a se restabelecidos e reconhecidos. São eles:

1. A essência da música não reside em um programa ou em uma teoria, nem na experimentação e nem na estrutura. Sua essência encontra-se na melodia. A melodia como tal eleva o coração e 
revigora os espíritos; ela é cantada pelo povo em vista da facilidade com que pode ser gravada na memória, mas ela não é, por essa razão, nem banal e nem repreensível.

2. Nem toda a música é acessível a todos. Por este motivo, a música popular deve ser a preferida porque atrai um grande público. Isso é especialmente verdade em uma época na qual os líderes da nação são obrigados a proporcionar relaxamento, diversão e restauro para o seu povo, o qual é atualmente confrontado com ansiedades profundas.

3. Como qualquer outra forma de arte, a música tem suas origens nos poderes misteriosos e profundos enraizados no caráter popular. Ela pode, portanto, ser moldada e formatada de um modo adequado às necessidades do povo, e seu poderoso dinamismo em fazer música ser realizado apenas pelos descendentes que estão mergulhados em sua herança nacional. Judaísmo e música alemã são opostos, pois por sua própria natureza, encontram-se em radical contradição. A luta contra o judaísmo na música alemã que Richard Wagner, sozinho e sem qualquer ajuda ou apoio, uma vez assumiu, é ainda a razão de nossa grande tarefa atual. Esta batalha não é mais a batalha de um gênio experiente.

4. A música é a mais sensual das artes e por isso apela mais para o coração e para as emoções do que para o intelecto. Mas onde o coração de uma nação bate mais forte do que nas massas, onde o coração de uma nação está verdadeiramente em casa? 0 dever inevitável de nossos líderes musicais é, portanto, deixar o povo compartilhar dos tesouros da música alemã.

5. Para uma pessoa musical, ser não musical é mais ou menos como ser cego ou surdo. Agradeço a Deus que gentilmente criou a música para ouvir, experienciar e amar apaixonadamente.

6. A música é a forma de arte que mais comove o espírito humano; ela tem o poder de aliviar a dor e de transformar a mera felicidade em êxtase.

7. Se a melodia é a fonte da música, segue-se que a música para o povo não pode ser limitada a pastorais ou corais. A música deve sempre retornar à melodia vivaz, à raiz de sua existência.

8. Em nenhum lugar os tesouros do passado são tão ricos e inesgotavelmente fartos como na área da música. Mantê-los e, em seguida, oferecê-los ao povo é a nossa missão mais importante e gratificante.

9. Às vezes, a linguagem dos sons musicais é mais eficaz do que a linguagem das palavras. Por esta razão, os grandes mestres do passado representam a verdadeira majestade do nosso povo e são merecedores de reverência e respeito.

10. E como filhos de nosso povo, eles são os verdadeiros monarcas do nosso povo pela graça de Deus e estão destinados a receber a fama e a honra de nossa nação e multiplicar-se (HUENER \&NICOSIA, 2006: 183-184).

Os 'Dez Princípios' de Goebbels, discurso de teor essencialmente emocional, simplista, marcadamente nacionalista e repleto de crenças de senso comum, deixa bem claro o ponto de vista estético e ideológico defendido por ele, e consequentemente, pelos 
TOMÁS, Lia. Música em tempos sombrios: apontamentos sobre a estética musical no III Reich. Per Musi. Ed. por Fausto Borém e Lia Tomás. Belo Horizonte: UFMG, n.35, p.79-99.

demais companheiros de partido, incluindo-se aí o próprio Führer. Analizando o texto, podemos depreender que para a cúpula do Reich:

a) a música é uma linguagem estritamente emocional, e portanto, quaisquer tentativas de especulação intelectual a seu respeito são completamente inúteis e desprovidas de sentido;

b) oriunda do 'seio do povo', a música está, portanto, intrinsecamente ligada ao conceito de caráter nacional, de solo, de raça e de identidade;

c) a música popular (entendendo-se sobretudo a de extração folclórica) é a expressão espontânea dos sentimentos do povo, do caráter nacional e de sua história, cuja função é sempre dupla: ao mesmo tempo em que possibilita o retorno a uma origem seja dela própria, da nação ou do povo - por meio da rememoração, sua reatualização contínua pelas práticas musicais também apazigua o espírito frente as mazelas do tempo presente. Em outros termos, cinde o tempo presente por meio de uma fissura e realoca - mesmo que brevemente - o povo em seu passado glorioso, não importando aqui se esse passado é real ou apenas fruto de uma falsa reconstrução;

d) a música é uma criação divina; assim como a religião ou a idolatria por algum lider, ela pode arrebatar, extasiar, transformar, transcender e purificar o espírito por meio de sua comoção;

e) a música é muito mais persuasiva que a linguagem verbal, pois ela promove e estimula uma atitude devocional e missionária;

f) Tal como fizera Wagner, a missão dos músicos alemães e de todo o aparato governamental que os sustentavam, era eliminar quaisquer elementos perturbadores que colocassem em xeque a tradição musical (elementos estritamente musicais, estéticos ou políticos e mesmo pessoas, como os judeus), bem como preservar e difundir a herança musical alemã; do mesmo modo como esses músicos honravam seu passado imediato, deveriam também ser vistos como legítimos herdeiros de tais 
TOMÁS, Lia. Música em tempos sombrios: apontamentos sobre a estética musical no III Reich. Per Musi. Ed. por Fausto Borém e Lia Tomás. Belo Horizonte: UFMG, n.35, p.79-99.

méritos; e o povo, por sua vez, deveria se comportar como merecedor dessas honrarias.

Nesta brevíssima análise, vimos que o discurso de Goebbels entrelaça diversos conceitos, pois sendo a música o mais importante instrumento de controle ideológico utilizado pelo partido, os conceitos de nação, povo, caráter nacional, religião e também música podem também ser tomados, em diversas circunstâncias, como sinonímicos. No entanto, antes de prosserguirmos por esta senda, caberia perguntar se estes princípios defendidos por Goebbels seriam originais, próprios de um dos mentores do nacional-socialismo ou encontravam-se assentados (mesmo que muito dispersos) em variados viezes do passado histórico alemão.

Com o intuito de resgatar essa rota, recorremos aqui ao sociólogo Norbert Elias, o qual poderá nos auxiliar na compreensão de parte da construção desse percurso. Em seu livro Os alemães: a luta pelo poder e a evolução do habitus nos século XIX e XX' (1997:16-29), Elias assinala quatro particularidades na formação do estado alemão que diferem em muito dos demais estados europeus, tais como a França e a Inglaterra ${ }^{1}$.

A primeira dessas particularidades refere-se à localização geográfica das tribos de fala germânica, situadas em um extenso território entre o rio Elba e os Alpes. Esse território encontrava-se encravado entre tribos cujas línguas derivavam-se do latim e das línguas eslavas e por essa razão, esses três grupos lutaram por séculos pela demarcação de suas terras: suas fronteiras eram constantemente movediças, ora tendendo mais para o lado eslavo ou latino, ora tendendo mais para os germânicos. Essa constante mobilidade fronteiriça propiciou um fortalecimento necessário das zonas límitrofes e periféricas desse grande território, em detrimento da construção de um centro de poder do qual emanasse as diretrizes gerais de organização desse. Deriva-se ainda disto, a construção de Estados independentes dentro de um mesmo grupo linguístico.

${ }^{1}$ Cf. também BLICKE (2004:48-51). 
A segunda, a qual está diretamente relacionada com o primeira, vincula-se não apenas às constantes disputas pelas fronteiras mas sobretudo às profundas marcas que esses episódios de luta impuseram na identidade interna dos germânicos. Visto que muitas dessas tribos ou grupos sociais foram derrotados violentamente e incorporados a outras tribos e grupos, os perdedores tiveram que conviver com a certeza de que nunca mais voltariam a ser o que foram, pois sua condição mudara para uma categoria inferior. 0 que lhes restou foi viver à sombra de um passado glorioso (real ou imaginário), porém irrecuperável.

A terceira particularidade assinala a ruptura e a descontinuidade no processo de desenvolvimento do estado alemão. Atuais capitais europeias, como Paris e Londres por exemplo, desde muito séculos foram os centros urbanos de maior importância e a despeito das vicissitudes históricas, nunca deixaram de ser as principais cidades de seus territórios. A existência de monumentos históricos antigos nessas cidades é um aspecto que confirma essa tradição ininterrupta. Quanto à Alemanha, entretanto, o mesmo não ocorreu visto que o centro de poder foi alternado com frequência. Quando comparada às cidades citadas, Berlim como capital é uma cidade jovem, pois Viena e Praga também foram capitais deste vasto território em épocas e em circunstâncias diferentes.

Elias acrescenta ainda neste ponto, o modo de vida e a administração autônoma de algumas cidades alemãs na Idade Média. Segundo o autor, diversamente de outros centros urbanos, a cultura urbana alemã desempenhava um papel menor, pois as monarquias absolutas extremamente centralizadas que ascenderam ao poder e a aristocracia da corte consideravam os mercadores urbanos como cidadãos de categoria menor, ou ainda, de segunda classe; e decorrente desse quadro social, no lugar do estabelecimento do modelo de negociação entre os extratos sociais que compunham as cidades, houve a prevalência de modelos militares de conduta, pautados no comando e na obediência. 
TOMÁS, Lia. Música em tempos sombrios: apontamentos sobre a estética musical no III Reich. Per Musi. Ed. por Fausto Borém e Lia Tomás. Belo Horizonte: UFMG, n.35, p.79-99.

A quarta e última particularidade refere-se ao período clássico da literatura e da filosofia alemãs, o qual foi caracterizado por uma eclosão de antagonismos entre a classe média e a nobreza da corte. Por não compartilhar atitudes e valores militares, a classe média foi praticamente impedida de acessar as atividades políticas e militares. Neste sentido, Goethe foi uma excessão como porta-voz de uma elite de classe média e que alcançou uma posição importante na corte de um príncipe. Esses fatores resultaram em um nítido distanciamento entre esses grupos sociais e já no século XIX, era possível vislumbrar duas correntes que se instauraram na classe média: uma idealista-liberal e outra conservadora-nacionalista.

Em paralelo a esse contexto e de modo contingencial, se estabelece também na futura Alemanha uma clara cisão entre "história política" e "história cultural", ou ainda: visto que a história política era um privilégio da classe aristocrática, a classe média, mesmo com certo poder aquisitivo mas alijada de tais prerrogativas, encontra seu ponto de apoio no domínio da cultura, compondo aí um quadro de referências de autolegitimação, de desenvolvimento e de manutenção de atitudes, crenças e condutas.

Veremos agora dois exemplos oriundos do campo da música, nos quais é possível identificar este viés de construção cultural ancorada no princípio de identidade nacional e alicerçado no domínio desse tipo de história. 0 primeiro deles encontra-se nas três últimas partes do XVIII capítulo do conhecido tratado de Johann Joachim Quantz, A Arte de tocar Flauta, de1752, e o segundo, advém do texto "O que é alemão?" de Richard Wagner, o qual foi publicado em fevereiro de 1878 no Bayreutter Blatter.

Com o intuito de fornecer diretrizes para o julgamento de um músico e de uma obra musical, Quantz aponta no final de seu tratado que

87. Quando alguém sabe escolher com bom discernimento o que há de melhor nos estilos das músicas de várias nações, o resultado é um estilo misto, que bem poderia chamar-se no presente, sem exceder os limites da modéstia, o estilo alemão: não apenas porque os alemães tiveram primeiramente a idéia, mas também porque este foi introduzido há muitos anos e em muitos lugares na Alemanha, ainda está florescendo e não desagrada na Itália, nem na França e nem em outros países. 
88. Se a nação alemã mantém esse estilo; se se esforça em conseguir sempre novos progressos, como até o momento têm feito seus mais célebre compositores; se seus compositores novatos se dedicam no presente em aprender a fundo as regras da composição, assim como as do estilo misto, e empregam-nas seguindo o exemplo de seus predecessores; se não se contentam com a melodia pura e em compor unicamente árias para o teatro, mas se instruem tanto no estilo da igreja como no da música instrumental; se em relação à organização interna das peças e à conexão e mescla razoável de idéias se propõem a usar como modelo compositores que tenham uma aprovação universal; se eles imitam sua maneira de compor e a fineza de seu gosto mas, entretanto, sem adornar-se com a plumagem alheia, como costumaram alguns que não somente copiam o tema mas comumente toda a conexão de uma peça de outro músico; se no lugar de fazer peças requentadas usam sua imaginação para mostrar e cultivar seus próprios talentos, sem prejudicar outros, esforçando-se para evitar uma continuidade em serem eternos copistas e no seu lugar chegam a ser compositores; se os instrumentistas alemães não se deixarem seduzir por uma maneira de tocar cômica ou estranha e não seguirem o mal exemplo dos italianos acima mencionados; se em seu lugar tomarem como modelo a boa maneira de cantar e os que tocam em um estilo razoável; se os italianos e os franceses quisessem imitar o estilo misto dos alemães da mesma maneira que os alemães imitaram os seus, então surgiria com o tempo um bom gosto universal na música. Isso é cada vez mais improvável, já que os franceses e os italianos, sobretudo os amantes da música de ambas as nações, já não se contentam com o simples estilo de seu país e desde há algum tempo, encontram mais prazer em certas composições estrangeiras do que nas próprias.

89. Um estilo que consiste, como o dos alemães de hoje, em uma mistura judiciosa dos estilos de outras nações, cada nação encontra semelhança com seu estilo próprio, o qual não pode desagradar nunca. Ainda assim, ao refletir sobre todas as coisas ditas sobre a diferença entre os estilos, haveria que se reconhecer certa preferência pelo estilo simples dos italianos sobre o dos franceses, não obstante reconhecendo que o primeiro não é tão sólido como fora no passado, tornando-se muito mais estranho e desenfreado, e que o outro se manteve demasiado simples, um estilo misto e composto do melhor de ambos deve ser, sem sombra de dúvidas, muito mais universal e agradável. Já que uma música é bem recebida e aprovada por várias pessoas - e não apenas em uma única província, em um único país ou em uma nação em particular -, tal música deve ser a melhor porque se baseando nas regras da razão sadia e no sentimento justo, só pode, pelas razões que ofereci perceber-se como verdadeiramente boa (QUANTZ, 1752: 334-336).

\footnotetext{
Para justificar sua defesa do "estilo alemão" em música, Quantz resgata uma conhecida querela histórica entre as músicas francesa e italiana, tece críticas ao modo de compor desses países e propõe como solução um "estilo misto", ou ainda, um estilo constituído pela melhor parte da música de todas nações, cuja pujança e aceitação por
} 
TOMÁS, Lia. Música em tempos sombrios: apontamentos sobre a estética musical no III Reich. Per Musi. Ed. por Fausto Borém e Lia Tomás. Belo Horizonte: UFMG, n.35, p.79-99.

todos referenda não apenas a supremacia da música alemã, como também a sua universalidade.

As qualidades dos músicos alemães também são enaltecidas e encontram-se prescritas no texto acima, estendendo-se ainda para uma normatização da própria música a ser composta: por serem melhor preparados nos aspectos técnicos da composição musical, os músicos alemães devem perseverar na versatilidade de estilos musicais, em uma sofisticação criativa da escrita, em uma originalidade sem pedantismos e na manutenção de uma disciplina em seu ofício.

O apelo de Quantz ao estilo misto também pode ser lido como uma estratégia de síntese de natureza cosmopolita, na medida em que este congrega não somente o melhor das nações, mas fundamenta de modo análogo, o melhor julgamento e sensibilidade. Mesmo que nesse momento a Alemanha ainda não estivesse constituída efetivamente como uma nação, é no 'melhor' desse conjunto de qualidades que a futura base nacional será alicerçada. Nas palavras de Sponheuer,

\begin{abstract}
Quantz criou uma grande síntese, um paradigma um tanto irreal e idealista da universalidade da linguagem musical, que estaria distante das diferenças entre as linguagens nacionais. Deste modo, Quantz inaugurou um modelo conceitual que basicamente tornou-se intacto nas discussões subsequentes sobre o "alemão em música" (SPONHEUER, 2002: 47).
\end{abstract}

As características apontadas por Quantz quanto ao que seja "alemão em música" comparecem anos depois, com uma nova roupagem, no discurso de Wagner. Com pinceladas mais intensas e dramáticas, o compositor inicia o texto "0 que é alemão?" relembrando a gênese do povo germânico, relatando com detalhes os percalços históricos aos quais foram submetidos, as guerras, as perdas, as glórias e os triunfos.

Em variadas passagens, Wagner assinala enfaticamente o vínculo indissociável entre a identidade nacional e o caráter do povo, a preservação intacta da língua alemã e dos costumes. Mesmo tendo passado por intermpéries e mazelas no decorrer dos séculos, 
TOMÁS, Lia. Música em tempos sombrios: apontamentos sobre a estética musical no III Reich. Per Musi. Ed. por Fausto Borém e Lia Tomás. Belo Horizonte: UFMG, n.35, p.79-99.

os legítimos alemães nunca se deixaram contaminar e influenciar totalmente por elementos estrangeiros, pois a firmeza de sua índole fora cultivada não apenas nos confrontos sangrentos dos campos de batalha, mas sobretudo na intimidade do lares, na rotina comezinha dos vilarejos, nas reuniões festivas das cidades, na escuta das narrativas sobre os ancestrais, enfim....Ouçamos Wagner:

“[...]É em torno da ideia de língua e pátria originária que o conceito deutsch se forjou, e de acordo com ele, chegou o tempo em que esses Deutschen puderam colher as vantagens de uma semelhante fidelidade a seu solo e língua ancestral. [...]

[...] Depois que se produzira a mais completa prostração da natureza alemã, depois que enfrentamos a quase total extinção nacional como consequência das devastações da Guerra dos Trinta Anos, este íntimo mundo doméstico constituiu o ponto de partida do renascimento do "espírito alemão": a poesia alemã, a música alemã, a filosofia alemã são altamente estimadas e honradas por todas as nações da terra [...]

[...] Deutsche é o nome dado às raças germânicas que permaneceram em seu solo natal e conservaram íntegros sua língua e costumes [...]

[...] Um povo que viu sua população reduzida a um décimo de seu número anterior à guerra, só poderia conseguir sobreviver se sua significação sobrevivesse na memória de cada um dos membros sobreviventes. Inclui-se que essa memória teria, em primeiro lugar, que ser revivida e trabalhosamente reconstruída começando pelas mais ilustres mentes [...] A recordação (Erinnerung) convertia-se agora em realidade, em um processo de autoconsciência e autodescobrimento (Er-Innerung); a partir de sua interioridade mais profunda, o alemão se modelou a si mesmo com o desejo de protegerse das novas e poderosas influências externas [...] Mas quando até a nativa aparência exterior de sua língua estava se perdendo, permaneceu para o espírito alemão um último reduto, um santuário jamais imaginado de onde poderia comunicar a história de seu coração a outros corações. Dos italianos, os alemães haviam adotado a música em seu proveito. Quem quiser apreender a magnífica individualidade, pujança e significação do espírito alemão mediante uma imagem incomparavelmente expressiva, olhe penetrantemente a figura do músico mais enigmático e de aparição mais inexplicável, que não é outro que Johann Sebastian Bach. Bach resume a história da vida interior do espírito alemão durante a traumática centúria que produziu a quase completa extinção da Alemanha como povo. Observem essa cabeça, absurdamente coberta quase que por completo com a peruca francesa; contemplem esse maestro, um pobre organista e cantor que deslocou-se de um lugar a outro ao redor de sua Turíngia natal, empregando-se em diminutas localidades, muitas das quais já não nos soam o nome; tenham em conta a indiferença que rodeou sua vida, até o ponto em que foi necessário passar um século para resgatar suas obras do esquecimento; considerem que em sua época, a música estava sujeita a formas artísticas que eram a verdadeira imagem da secura, da rigidez e do pedantismo, como se lhe tivessem colocado peruca e trança nas notas, e admirem o mundo de profundidade insondável que o grande Sebastian construiu a partir desses elementos. Eu me 


\begin{abstract}
limito a apontar meramente o que essa criação significa, já que é impossível chegar a expressar sua riqueza e sublimidade ou a importância de uma obra que abarca tudo, utilizando a medida normal dos termos. Se agora aspiramos realizar um exame dos frutos alcançados pelo renascimento do espírito alemão nos campos da poesia e da filosofia, somente poderemos efetuá-lo depois de captar, através da figura de Bach, a essência autêntica do espírito alemão, pois foi em sua obra onde esse espírito reteve seu assento e começou sem pausa a forja de uma nova conformação, precisamente quando parecia ter sido aniquilado e condenado a desaparecer do mundo... [...]"(WAGNER, 2012).
\end{abstract}

Os comentários faustosos e comoventes de Wagner sobre a figura de Bach sintetizam diversos componentes que caracterizam, segundo seu ponto de vista, a identidade nacional alemã - ou "espírito alemão", como ele mesmo o denomina - e também se inserem em uma vertente que dominou parte da crítica musical do século XIX alemão, a saber, a monumentalidade musical. Esse tipo de visão historiográfica por assim dizer, que floresceu nos primórdios do século XIX e foi amplamente difundida pelo Allgemeine musikalische Zeitung - o mais importante periódico dedicado à música em seu tempo -, tinha como meta resgatar os grandes compositores alemães do passado, preservar sua memória e as respectivas obras, bem como confirmar o domínio e prestígio da música alemã sobre as demais produções europeias.

Alexander Rehding em seu livro Music and Monumentality (2009:19-28), reconstrói com detalhes essa importante faceta histórica que se encontra atrelada à música alemã. Rehding assinala que a perspectiva dos 'monumentos musicais' deve ser entendida como uma coleção de obras históricas, cuja significação demarca pontos importantes de seu desenvolvimento. Entretanto, no contexto em que essa visão se tornou uma diretriz nos artigos publicados pelo Allgemeine, as justificativas de Friedrich Rochlitz, seu primeiro editor, não se restringem apenas ao resgate de obras e/ou personagens que pudessem ser tomados como exemplos da cultura germânica, mas as tomam como pressupostos de um dos aspectos assinalados por Norbert Elias, a saber, a descontinuidade no processo de desenvolvimento do estado alemão.

No texto "Monumente deutscher Tonkünstler", Rochlitz afirma que várias cidades europeias já desempenhavam, desde longa data, o papel de capital de seus territórios e que por esse motivo, também possuíam monumentos que eram reconhecidos como 
TOMÁS, Lia. Música em tempos sombrios: apontamentos sobre a estética musical no III Reich. Per Musi. Ed. por Fausto Borém e Lia Tomás. Belo Horizonte: UFMG, n.35, p.79-99.

marcos da história de suas nações, como Londres, com a Abadia de Westminster e Paris, com o Panthéon. No entanto, ele se pergunta: frente a isso, o que a Alemanha tem a oferecer?

Na alvorada do século XIX, a Alemanha efetivamente não possuía nenhuma capital, mas sim "capitais", pois o território germânico não tinha construído ainda uma genuína unidade política; no entanto, essa mesma Alemanha já produzira um considerável número de compositores que eram internacionalmente reconhecidos, como Haendel, Gluck e também Mozart e Haydn, e suas obras já começavam a se esboçar como modelos. Assim, o reconhecimento da qualidade da produção musical alemã por uma grande número de pessoas desempenhava aqui, não somente uma excelência artística, mas cumpria, sobretudo, um papel político².

Apesar das considerações acima, Rehding também destaca que a natureza dos monumentos já tinha ocupado espaço em reflexões anteriores ao nascimento do periódico e já fora esboçada. Em 1771, Johann Georg Sulzer, em sua enciclopédia Allgemeine Theorie der schönen Künste (Teoria Geral das Belas Artes) definira monumento como "obra de arte localizada em locais públicos com o objetivo de sustentar perpetuamente e disseminar para a posteridade, a memórias de pessoas notáveis ou objetos" (apud Rehding, 2009:21). Para Sulzer, uma simples inscrição, como uma placa fixada na fachada de um imóvel indicando que determinada pessoa vivera naquele local, poderia cumprir o objetivo mínimo; e considerando-se que para ele o propósito das artes era evocar emoções e sentimentos virtuosos, houve aqui uma coincidência entre os objetivos do monumento artístico e da própria arte. Traçou-se dessa forma, o perfil ou o objetivo da música como monumento, a qual finalmente encontrara seu destino.

O autor observa, entretanto, que o processo de construção da monumentalidade musical não ocorreu apenas por conta da publicação de um único artigo, pois à época, a prática musical em terras alemãs era bastante hererogênea e seria necessário

\footnotetext{
${ }^{2}$ Neste conjunto de argumentos, a influência do pensamento de Quantz é notória.
} 
TOMÁS, Lia. Música em tempos sombrios: apontamentos sobre a estética musical no III Reich. Per Musi. Ed. por Fausto Borém e Lia Tomás. Belo Horizonte: UFMG, n.35, p.79-99.

difundir a ideia de que a música poderia ter uma missão maior. Dentre uma série de autores que fomentaram essa ideia por meio do Allgemeine musikalische Zeitung, destaca-se Johann Karl Friedrich Triest, teólogo e colaborador regular. Em um de seus textos, Triest assinala a necessidade de um trabalho conjunto para que a música se tornasse uma potência mobilizadora, para que ela exercesse efetivamente seu genuíno papel catalisador de uma nascente consciência nacional. Portanto, questões como genialidade, subjetividade e gosto particular encerravam-se na esfera da individualidade, e nesse momento, não seria interessante para tais propósitos.

Mais um aspecto também merece destaque nesse contexto. Em paralelo às publicações do Allgemeine e o repertório vocal por ele enfatizado, a música instrumental crescia em importância e destacava-se no cenário musical desde o final do século XVIII. Autores como Wackenroder, Tieck e Hoffmann, por exemplo, já tinham enfatizado qualidades desse gênero que pareciam se adequar com perfeição a esse papel estético sugerido por Triest. À guisa de exemplo, o texto A essência singular da arte musical e a psicologia da música instrumental contemporânea de Wackenroder, enfatiza a capacidade expressiva da música instrumental e assinala que por essa razão, ela consegue expressar apenas por seus próprios sons, uma rede de significados mais elevados do que as palavras poderiam conseguir; por sua vez Tieck, em Sinfonias, ressalta a independência, a capacidade constitutiva de leis próprias, a liberdade e o caráter lúdico desse gênero musical, o qual por não ter um propósito fixo, realiza e alcança um objetivo muito superior; Hoffmann, em sua Recensão da Quinta Sinfonia de Beethoven, também destaca o potencial da música instrumental quanto à expressão essencial e genuína da arte, assim como a introspecção que ela pode sugerir ao ouvinte, apresentando-lhe um mundo totalmente apartado da realidade externa, isento de sentimentos definíveis por conceitos e entregue ao inefável.

Torna-se necessário esclarecer que a música a qual se referem os autores citados é aquela que posteriormente foi nomeada e identificada como 'música absoluta'; no entanto e a despeito de uma identificação imediata desta com a música monumental, existe uma sutil diferença entre elas. Como destaca o musicólogo A. Rehding, 


\begin{abstract}
Em poucas palavras, com sua importante tarefa de invocar memórias, o monumento pretende significar. Como um artefato que carrega uma mensagem, codificada ou explícita, abstrata ou concreta, a música monumental não é, por definição, nem independente e nem desprovida de função social. Em outras palavras, a música monumental não pode ser absoluta -, no sentido estrito de ser sem palavras, não referencial e com entidades musicais não funcionais [...] O conceito de Werktreue, ou fidelidade da obra, significa algo muito diferente no contexto da música monumental (2009: 26).
\end{abstract}

E complementando, o autor afirma que a música monumental pode ser entendida como uma espécie de corruptela da música absoluta, pois ela é não intencional com um propósito: ao largo do prestígio que a música instrumental conquistou no século XIX, desempenhando o papel de realidade metafísica do absoluto no imaginário romântico, a música monumental se aproveitou desse prestígio de forma parasitária, cercada de rituais, de práticas e de autoridade (REHDING, 2009: 26).

$* * * * * * * * * * * * * * * * * *$

Voltemos agora ao cenário alemão dos anos trinta, à constituição da Câmara da Cultura do Reich e de seu principal personagem, Joseph Goebbels.

Quando da implantação das medidas raciais promulgadas em 1933, a vida musical alemã passou por uma grande turbulência: orquestras foram obrigadas a demitir profissionais por conta de sua ascendência, professores universitários foram impedidos de exercer suas funções ou 'convidados' a desenvolver pesquisas musicológicas voltadas para a diretiva "música e raça", maestros competentes foram depostos sem justificativas. Frente a esse quadro, o maestro Wilhelm Furtwängler, então titular da Ópera de Berlim, escreveu uma carta a Goebbels em 11 de abril do mesmo ano, defendendo a autonomia da arte frente à politização que começara a se implantar e pedia ainda que os colegas de profissão Bruno Walter e Otto Kemplerer, fossem deixados em seus postos de trabalho. Goebbels respondeu à missiva e solicitou ainda ao maestro, a permissão para que tal troca de correspondências fosse publicada no Vossische Zeitung, jornal liberal e de grande circulação. Vejamos alguns excertos: 
Furtwängler: Atualmente a vida musical, já seriamente enfraquecida pela crise mundial, a rádio, etc., não poderá suportar outras provações. Não podemos contingenciar a música como fazemos com os produtos essenciais, tais quais as batatas ou o pão. Se não oferecemos algo que valha a pena nos concertos, o público simplesmente não comparece. Assim, o problema da qualidade da música não é apenas um problema teórico, mas um problema simplesmente vital. Se a luta contra o judaísmo é dirigida, em primeiro lugar, contra os artistas desenraizados e destrutivos que só procuram se valorizar pelo kitsch, pela virtuosidade dessecada, etc. tudo está correto. A luta contra esses e contra o espírito que eles encarnam - e que, aliás, domina também uma grande quantidade de elementos germânicos - só poderia ser realizado de um modo bem defensivo e enérgico. Mas se esta luta é dirigida contra os verdadeiros artistas, ela não é do interesse da vida cultural, primeiro porque os artistas, onde quer que estejam, são muito raros para que um país possa se permitir a renúncia de suas realizações sem sofrer prejuízos no plano cultural.

Goebbels: É seu direito pessoal sentir-se artista e olhar para os fatos da vida de um ponto de vista artístico. Entretanto, isso não implica que o senhor tenha uma posição não política a respeito do conjunto de fenômenos que ocorre na Alemanha. A política é também uma arte, talvez a arte mais elevada e mais ampla que existe, e nós que damos a forma na política alemã moderna, nos sentimos como artistas aos quais foi confiada a grande responsabilidade de formar, a partir da massa bruta, a imagem sólida e plena do povo. A missão da arte e do artista não é apenas unir, ela vai mais longe. É seu dever criar, dar forma, eliminar o que é doentio e de abrir a via ao que é são. Assim, enquanto homem político alemão, eu não posso reconhecer esta única linha de separação que existe, segundo seus argumentos: a linha que separa a arte de qualidade da arte sem qualidade. A arte não pode ser apenas de qualidade, ela deve também emergir do povo, ou mais precisamente, apenas uma arte extraída integralmente do Volkstum pode ser, no final das contas, de qualidade e significar alguma coisa para o povo, ao qual ela é destinada.

A arte absoluta, tal qual concebe a democracia liberal, não deve mais existir. A tentação de utilizá-la servirá em última análise, para que o povo não tenha mais uma relação íntima com a arte e que o próprio artista se mova no espaço vazio da ideia da arte pela arte, se isolando e se mantendo afastado das forças vivas de seu tempo. A arte deve ser de qualidade, mais igualmente consciente de suas responsabilidades, aceitável, próxima do povo e combativa. Que não possamos sofrer novas provações, eu estou totalmente de acordo. Entretanto, seria muito mais justificável protestar contra as experiências artísticas da época em que a vida artística alemã era quase exclusivamente dominada pela fúria experimental de elementos estrangeiros à raça $\mathrm{e}$ ao povo, o que, consequentemente, comprometeu a reputação artística da Alemanha aos olhos do mundo inteiro (BRENNER, 1980: 272-274).

A resposta dada por Goebbels a Furtwängler demonstra claramente sua falta de sensibilidade, ou ainda, sua obsessão compulsiva contra aspectos qualitativos sobre as artes, os quais, de um modo ou de outro, poderiam colocar em dúvida as premissas de seus argumentos. Seu bordão, dado como resposta, é retomado constantemente: a 
TOMÁS, Lia. Música em tempos sombrios: apontamentos sobre a estética musical no III Reich. Per Musi. Ed. por Fausto Borém e Lia Tomás. Belo Horizonte: UFMG, n.35, p.79-99.

arte, em todas as suas manifestações, é um instrumento político cuja valorização se dá mediante o engajamento às diretivas do partido; como instrumento de combate, a arte tem como alvo as produções artísticas realizadas durante a República de Weimar ou as atuais que não se adequem ideologicamente; a trilogia de conceitos raça, povo e nação são conceitos intercambiáveis e repetidos a exaustão; e a música, vista como um estímulo do orgulho nacional por ser a "expressão de uma raça", tornou-se seu cavalo-de-batalha.

Retomando A. Rehding, (2009: 169-178), o autor observa ainda que os mais bem sucedidos espetáculos realizados sob a égide da concepção estético-ideológica da monumentalidade musical, receberam o amparo intelectual de musicólogos e começaram a ser produzidos pouco antes das já citadas Jornadas Musicais de 1938. A música monumental, a funcionalização da música absoluta, utilizou-se com maestria de dois parâmetros de magnitude que frequentemente compareceram nas primeiras concepções dos monumentos musicais do século XIX: o primeiro deles, a grandeza histórica, relaciona-se diretamente com a memória coletiva e a formação de identidade nacional e o segundo, refere-se ao tamanho físico, demonstrando uma clara tendência a proporções dramáticas, com o intuito de provocar espanto e arrebatamento nos ouvintes. Esse último, frequentemente associado ao conceito de sublime, pode ser melhor entendido quando coligado a grandiosidade, ao bombástico ou ainda, em uma estética do assombro. E neste sentido, fica claro que o papel arquitetônico, o papel espacial ocupado pela música desempenha um lugar fundamental.

Já em 1935, o musicólogo Arnold Schering33pondera que na natureza da música monumental, a magnitude não se relaciona diretamente com a duração da obra

\footnotetext{
${ }^{3}$ A. Schering (1877-1941) foi um reputado musicólogo alemão que se notabilizou pelos trabalhos relativos a Bach e demais autores alemães dos séculos XVI, XVII e XVIII. Em 1920, sucedeu Abert como professor de música em Halle, e em 1928 mudou-se para Berlim, onde ocupou a cadeira de musicologia até sua morte. Schering atuou como diretor de Denkmäler Deutscher Tonkunst (uma edição histórica da música alemã, publicada entre 1894 e 1952, que cobria os períodos Barroco e Clássico), presidente do Händel-Gesellschaft (Sociedade Händel) e presidente do Deutsche Musikgesellschaft (Sociedade Musical Alemã) em 1933. Quando no exercício desse último cargo, supervisionou a reorganização dessa sociedade em princípios nacional-socialistas e autorizou a demissão de Alfred Einstein, o editor judeu de sua revista.
} 
TOMÁS, Lia. Música em tempos sombrios: apontamentos sobre a estética musical no III Reich. Per Musi. Ed. por Fausto Borém e Lia Tomás. Belo Horizonte: UFMG, n.35, p.79-99.

durante a sua apresentação, porém com o espaço no qual ela está sendo executada associado com sua estrutura tonal:

\begin{abstract}
A obra monumental em música não pode ser imaginada em um espaço musical restrito. Sua extensão é alcançada por soar em uma ampla base tonal, por ter a predominância de harmonias simples e um certo esplendor e plenitude de som. A imaginação não concebe estes efeitos como um mero reforço da normalidade, longe disso; em seu lugar, a impressão sensual é direcionada a uma representação inconsciente, reproduzindo o espaço acústico correspondente a esses eventos sonoros extraordinários. (apud REHDING, 2009: 172)
\end{abstract}

Em outros termos, a música monumental deveria sempre preencher vastos espaços com sons imaginários, pois idealmente esses espaços transmitem uma sensação deinfinitoe de transcendêcia. A chave para este efeito residia na simplicidade e na clareza formal das composições musicais. Schering sugere, nesse caso, o uso do cantus firmus, técnicas de ostinato e formas fugais ${ }^{4}$. No entanto, todas estas técnicas estavam coligadas com o intuinto de supostamente transmitir uma sensação deuma "lei única", de uma imagem que possibilitou uma associação com o sublime.

Para a realização dessa proposta de espetáculo sonoro, Albert Speer, o conhecido arquiteto do nazismo, ocupou um papel importantíssimo e sua ideia de "catedral de luzes" foi fundamental. Essas catedrais consistiam no uso de 130 holofotes antiaéreos colocados verticalmente ao redor de grandes espaços, em um intervalo de 12 metros entre eles, com o intuito de criar uma série de barras verticais ao redor da plateia. 0 efeito era um grande brilho, tanto dentro como fora desse espaço, forjando um senso de comunidade aos participantes em um espaço virtual.

Tais eventos claramente propagandísticos incluíam ainda fanfarras para cercar o público com o som vindo de todos os lados. 0 conhecido e gélido cartaz concebido por

\footnotetext{
${ }^{4}$ Nesse sentido, a observação de Richard J. EVANS (2011:236) parece se encaixar adequadamente: "se alguma obra musical de destaque composta sob o Terceito Reich ajustava-se à idéia nazista de cultura, Carmina Burana [de Carl Orff] com certeza era essa obra: a tonalidade crua, os ritmos brutais e repetitivos, os textos medievais e as melodias populares, a pulsação entorpecente e insistente, a ausência de qualquer coisa para ocupar a mente pareciam varrer todas as excrescências da modernidade e do intelectualismo que o nazismo tanto detestava e levar a cultura de volta para a suposta simplicidade primitiva do passado camponês distante".
} 
TOMÁS, Lia. Música em tempos sombrios: apontamentos sobre a estética musical no III Reich. Per Musi. Ed. por Fausto Borém e Lia Tomás. Belo Horizonte: UFMG, n.35, p.79-99.

Lothar Heinemann também se apropria dessa idéia da catedral de luz: uma águia envolvendo com suas asas iluminadas os tubos de um órgão e abaixo o slogan "Alemanha, o país da música". À medida que o observador move o seu olhar ao longo dos tubos de órgão, eles gradualmente se transformar em penas estilizadas formando as asas poderosas de uma águia, o animal simbólico do Terceiro Reich. Nesse emblema, música, espaço e nação encontram-se finalmente combinados.

Vimos, assim, que neste conjunto de ideologias e, sobretudo de práticas associadas à música, a universalidade da música alemã e a universalidade do Estado alemão confirmam sua identidade absoluta. Para alcançar tais objetivos, o Terceiro Reich amparou-se no resgate das tradições, fossem elas legítimas ou inventadas, fixou práticas e rituais visando conclamar o sentimento comunitário e o dever em detrimento das individualidades.

A repetição exaustiva e formalmente invariável das manifestações musicais pretendia atingir a memória musical dos ouvintes e criar, mesmo que de modo circunstancial, um sentido de coletividade e de lealdade que apoiaria, sem restrições, a longa jornada da construção do Reich de Mil Anos. Afortunadamente, o eco desse moto perpetuo exauriu-se muito antes do previsto.

\section{Referências}

1. APPLEGATE, C., POTTER, P. (2002) Germans as the 'People of Music': Genealogy of an Identity. In: APPLEGATE, C., POTTER, P. (Ed.). Music \& German National Identity. Chicago \&London: The Universityof Chicago Press.

2. BREnNER, H. (1980) La Politique Artistique du National-Socialisme.Trad. L. Steinberg. Paris: François Maspero.

3. BLICKE, P. (2004) Heimat: a critical theory of German idea of homeland. Rochester: Camden House.

4. DÜMLING, A. (2004) Les Journées musicales du Reich et l'exposition 'Musique dégénérée'. In : HUYNH, P. (Ed.). Le III Reich et la Musique. Paris: Cité de la Musique/Fayard. 
TOMÁS, Lia. Música em tempos sombrios: apontamentos sobre a estética musical no III Reich. Per Musi. Ed. por Fausto Borém e Lia Tomás. Belo Horizonte: UFMG, n.35, p.79-99.

5. ELIAS, N. (1997) Os alemães: a luta pelo poder e a evolução do habitus nos século XIX e XX. Trad. A. Cabral. Rio de Janeiro: Jorge Zahar Editor.

6. ETLiN, R. A (Ed.). (2002) Art, Culture and Media under the Third Reich. Chicago: The University of Chicago Press.

7. EVANS, R. J. (2011) 0 Terceiro Reich no Poder. Trad. L. Brito. São Paulo: Planeta.

8. “GROVE MUSIC ONLINE”. (2014) Disponível em: http://www.oxfordmusiconline.com. Acessado em: 14 janeiro 2014.

9. HOBSBAWM, E.; RANGER, T. (2006) A invenção das tradições. Trad. C. C. Cavalvanti. Rio de Janeiro: Paz e Terra.

10. HUENER, J. \& NICOSIA, F. R (Orgs.). (2006) The Arts in the Nazi Germany: Continuity, Conformity, Change.Vermont: Berghahn Books.

11. HUYNH, P. (Ed.). (2004) Le III Reich et la Musique. Paris: Cité de la Musique/Fayard.

12.____ (1998) La Musique sous la République de Weimar. Paris: Fayard.

13. KATER, M. H. (2000) Composers of the Nazi Era: Eight Portraits. New York/Oxford: Oxford University Press.

14. POTTER, P. (2002) Musicologia e Nazismo. In: EINAUDI, G. (Ed.) Enciclopedia della Musica II: il sapere musicale. Milão: Einaudi.

15. QUANTZ, J. J. (1752) Essai de une méthode pour apprendre à jouer de la flute traversière. Berlin: Chrethien Frederic Voss. Disponível em: https://archive.org/stream/essaidunemthode00quangoog\#page/n307/mode/2u $\mathrm{p}$

16. REHDING, A. (2009) Music and Monumentality: Commemoration and Wonderment in Nineteenth-Century Germany. New York: Oxford University Press.

17. SAFRANSKI, R. (2010) Romantismo: uma questão alemã. Trad. R. Rios. São Paulo: Estação Liberdade.

18. SPONHEUER, B. (2002) Reconstruction Ideal Types of the 'German' in Music. In: APPLEGATE, C., POTTER, P. (Ed.). Music \& German National Identity. Chicago \& London: The University of Chicago Press.

19. STACKELBERG, R. \& WINKLE, S. A. (2002) The Nazi Germany Sourcebook: an Anthology of Texts. London and New York: Routledge.

20. SWEERS, B. (2005) The power to influence minds: german folk music during the Nazi era and after. In: RANDALL, A. J. (Ed.). Music, Power and Politics. New York: 
TOMÁS, Lia. Música em tempos sombrios: apontamentos sobre a estética musical no III Reich. Per Musi. Ed. por Fausto Borém e

Routledge.

21. TOMÁS, L. (2013) A música e seu uso político no III Reich. In: GARCIA, T. da C., TOMÁS, L. (Orgs). Música e Política: um olhar transdisciplinar. São Paulo: Alameda.

22. WAGNER, R. (2012) Que es alemán? Trad. A. Alamino. Disponível em: http://www.archivowagner.com $\backslash$ escritos-de-richard-wagner/177-w/wagnerrichard-1813-1883/493-que-es-aleman. Acessado em: setembro 2012.

Nota sobre a autora

Lia Tomás é Livre-Docente em Estética Musical (UNESP). Possui Bacharelado em Música (Instrumento Piano) pela UNESP - Instituto de Artes (1985), Mestrado e Doutorado em Comunicação e Semiótica pela PUCSP (1993 e 1998), dois PósDoutorados em Estética Musical (Université de Paris I - Institut d'Esthétique et des Sciences de l'Art)(2001 e 2003). Coordenou o Programa de Pós-Graduação em Música da UNESP - Instituto de Artes de 2007 a 2013 (duas gestões) e foi 1a Secretária da ANPPOM (Associação Nacional de Pesquisa e Pós-Graduação em Música), de 2008 a 2011. Atualmente é membro titular da Comissão Permanente de Avaliação (CPA) da Reitoria da UNESP e do GRAI/Avaliação Institucional da UNESP. No Instituto de Artes (UNESP-IA), coordena o DeMusica: Laboratório de Estudos em Estética Musical e Filosofia da Música (Projeto CNPq). 